\title{
PENERAPANMODEL PROJECT BASED LEARNING MENULIS PUISI MAHASISWA MANAGEMEN UNISSULA
}

\author{
LELI NISFI SETIANA' DAN AIDA AZIZAH² \\ Universitas Islam Sultan Agung \\ lelinisfi@unissula.ac.id!, aidaazizah@unissula.ac.id²
}

Pertama Diterima: 9 Januari 2019

Bukti Akhir Diterima: 15 Juni 2019

\begin{abstract}
Abstrak
Tujuan penelitian ini adalah megetahui hasil menulis puisi pada mahasiswa prodi manajemen berbasis model Project Based Learning. Pemilihan model Project Based Learning (PBL) memberikan kesempatan pada mahasiswa untuk membangun pengetahuannya sendiri, kepada mahasiswa dalam menghasilkan produk berupa karya tulis. Metode penelitian ini menggunakan teknik analisis data berupa model analisis mengalir, meliputi tiga komponen yaitu reduksi data, penyajian data, dan penarikan simpulan. Hasil penelitian ini mengevaluasi produk hasil karya puisi mahasiswa berbasis model Project Based Learning (PBL). Penilaian puisi hasil penulisan dari mahasiswa mengandung 4 elemen yaitu (1) kebaharuan tema dan makna, (2) kekuatan imajinasi, (3) ketepatan diksi, dan (4) pendayaan pemajasan dan citraan. Selanjutnya hasil penilaian tersebut diaplikasikan dalam bentuk materi pembelajaran bab kesantunan dalam berbahasa Indonesia yang baik dan benar.
\end{abstract}

Kata Kunci: project based learning, menulis puisi

\begin{abstract}
The purpose of this study is to find out the results of writing poetry in Management Study Program students based on Project Based Learning models. The selection of Project Based Learning (PBL) models gives students the opportunity to build their own knowledge, to students in producing products in the form of writing. This research method uses data analysis techniques in the form of a flow analysis model, which includes three components, namely data reduction, data presentation, and drawing conclusions. The results of this study evaluate the products of student poetry based on Project Based Learning (PBL) models. Poetry assessment written by students contains 4 elements, namely (1) the renewal of themes and meanings, (2) the power of imagination, (3) accuracy of diction, (4) enhancement of images and images. Furthermore, the assessment results are applied in the form of learning material politeness chapters in Indonesian that is good and right.
\end{abstract}

Keywords: project based learning, writing poetry

\section{PENDAHULUAN}

Bahasa merupakan alat komuikasi yang memungkinkan manusia untuk saling berhubungan, saling berbagi pengalaman, saling memberi masukan, dan saling belajar dengan yang lain. Menurut Chaer (2006:1) bahasa adalah suatu sistem lambang berupa bunyi, bersifat arbitrer, digunakan oleh suatu masyarakat tutur 
untuk bekerja sama, berkomunikasi, dan mengidentifikasi diri. Komunikasi dengan bahasa ini dapat dilakukan secara lisan dan tertulis. Orang menggunakan keterampilan berbicara dan keterampilan menyimak, sedangkan dalam berkomunikasi secara tertulis orang menggunakan keterampilan membaca dan kerterampilan menulis.Bahasa berfungsi sebagai alat komunikasi. Manusia dapat menyampaikan ide, gagasan, pikiran kepada orang lain melalui bahasa. Bahasa itu sendiri terdiri dari ragam lisan dan tulis. Ragam lisan biasanya digunakan oleh manusia untuk berinteraksi langsung dengan orang lain ketika lawan bicaranya berada di hadapannya, dan wujud ragam lisan berupa tuturan atau ujaran. Sedangkan ragam tulis biasanya digunakan manusia untuk berinteraksi tak langsung dengan orang lain dan lawan bicaranya tidak berada di hadapannya, wujud ragam tulis berupa tulisan.

Keterampilan berbahasa hendaknya diajarkan sejak usia dini karena salah satu tujuan pembelajaran bahasa Indonesia tingkat SD adalah menikmati dan memanfaatkan karya sastra untuk memperluas wawasan, memperluas budi pekerti serta meningkatkan pengetahuan dan kemamapuan berbahasa. Agar tujuan tersebut tercapai, lembaga pendidikan memegang peranan yang sangat pentingdalam rangka meningkatkan kemampuan penguasaan dan penggunaan bahasa Indonesia yang baik dan benar.

Kemampuan menulis merupakan proses belajar yang memerlukan ketekunan berlatih, semakin rajin berlatih kemampuan menulis akan meningkat. Oleh karena itu, keterampilan menulis mahasiswa perlu ditumbuhkembangkan sehingga diharapkan mahasiswa mampu menulis khususnya dalam menghasilkan karya sastra seperti puisi. Keterampilan menulis puisi perlu ditanamkan kepada mahasiswa sehingga mereka mempunyai kemampuan untuk mengapresiasikan puisi dengan baik.Mengapresiasikan sebuah puisi bukan hanya ditujukan untuk penghayatan dan pemahaman puisi, melainkan berpengaruh mempertajam terhadap kepekaan perasaan, penalaran, serta kepekaan anak terhadap masalah kemanusiaan. Adanya tahapan dalam menulis ini sesuai dengan pendapat Akhadiah dalam Abidin (2012:181) bahwa menulis adalah sebuah proses, yaitu proses penuangan gagasan atau ide ke dalam bahasa tulis yang dalam praktiknya proses menulis diwujudkan dalam beberapa tahapan yang merupakan satu sistem yang utuh. Kenyataaan di lapangan menunjukkan bahwa kemampuan mahasiswa dalam menulis puisi masih kurang, khususnya mahasiswa diluar Prodi Pendidikan Bahasa dan Sastra Indonesia. Hal ini disebabkan adanya anggapan siswa bahwa keterampilan menulis puisi kurang penting dibandingkan dengan pelajaran kebahasaan lainnya, yang akhirnya berdampak langsung pada kemampuan mahasiswa yang mengalami kesulitan ketika diberi tugas menulis puisi. Kesulitan yang dihadapi mahasiswa yaitu menentukan tema dan pilihan kata yang tepat dalam pembelajaran menulis puisi.

Pembelajaran merupakan rangkaian peristiwa atau kegiatan terstruktur dan terencana dengan menggunakan sebuah atau beberapa jenis media. Untuk itu, kegiatan pembelajaran dirancang oleh guru seharusnya dikondisikan dengan memanfaatkan sumber belajar dan tercipta lingkungan belajar yang mendukung untuk membantu mahasiswa mengerti dan memahami pelajaran. Segi efektivitas, seorang dosen diharapkan mampu mengelola pembelajaran dengan baik. Penggunaan teknik yang tepat dapat menarik minat siswa dalam menulis puisi sedangkan pembelajaran monoton akan berpengaruh pada semangat belajar dan prestasi belajar mahasiswa. Pemilihan strategi melalui model pembelajaran yang relevan dengan standar kompetensi juga dapat memacu kemampuan serta minat belajar mahasiswa demi tercapainya optimalisasi kualitas pembelajaran dan pembelajaran bermakna. Penerapan model pembelajaran konvensional menggunakan metode demonstrasi dan ceramah, mahasiswa cenderung lebih banyak mendengarkan penjelasan dosen dan melaksanakan tugas jika dosen memberikan tugas/latihan dengan mencari karya orang lain dibandingkan dengan menghasilkan karya mereka sendiri. Hal ini mengesankan tidak adanya aktivitas dan kreativitas mahasiswa dalam menulis puisi sehingga ketika mahasiswa diberikan tugas untuk menulis puisi, mahasiswa manajemen dalam pembelajaran MKU Bahasa Indonesia terlihat kesulitan dalam menemukan ide dan menyusun kata-kata dengan bahasanya sendiri. Dampak pembelajaran ini adalah mahasiswa yang hanya menghafal konsep, bukan menerapkan konsep tersebut dalam kehidupan sehari-hari. 
Untuk itu, analisis kebutuhan menjadi hal yang penting dilakukan dalam merencanakan pembelajaran untuk mencapai tujuan/kompetensi pembelajaran agar tercipta pembelajaran yang efektif dan efisien.

Mengapresiasikan sebuah puisi bukan hanya ditujukan untuk penghayatan dan pemahaman puisi, melainkan berpengaruh mempertajam terhadap kepekaan perasaan, penalaran, serta kepekaan anak terhadap masalah kemanusiaan. Adanya tahapan dalam menulis ini sesuai dengan pendapat Akhadiah dalam Abidin (2012:181) bahwa menulis adalah sebuah proses, yaitu proses penuangan gagasan atau ide ke dalam bahasa tulis yang dalam praktiknya proses menulis diwujudkan dalam beberapa tahapan yang merupakan satu sistem yang utuh. Pemilihan Project Based Learning (PBL) menjadi solusi dalam pembelajaran serta memberikan kesempatan pada mahasiswa untuk membangun pengetahuannya sendiri, dengan begitu mahasiswa berinteraksi dengan teman dalam menghasilkan produk berupa karya tulis. Dalam proses pembelajarannya, mahasiswa melakukan eksplorasi, penelitian, interpretasi, sintesis, dan informasi untuk menghasilkan berbagai bentuk hasil belajar. Fokus pembelajaran terletak pada prinsip dan konsep inti dari suatu disiplin ilmu, melibatkan siswa dalam investigasi pemecahan masalah dan tugas-tugas bermakna yang lain, memberi kesempatan siswa bekerja secara otonom dalam mengontruksi. Hal ini diungkapkan oleh Thomas, dkk, dalam Strategi Pembelajaran Inovatif.

Kontemporer (Wena, 2009:114) menyatakan bahwa PBL merupakan model pembelajaran yang memberikan kesempatan kepada dosen untuk mengelola pembelajaran di kelas dengan melibatkan kerja projek. Dengan demikian PBL merupakan strategi yang cocok digunakan dalam meningkatkan keterampilan menulis puisi karena strategi ini menuntut mahasiswa untuk bekerjasama memecahkan sebuah masalah dan berpikir untuk menghasilkan produk nyata berupa sebuah tulisan dari permasalahan tersebut.Menulis merupakan suatu keterampilan berbahasa yang dipergunakan untuk berkomunikasi secara tidak langsung. Hal ini dapat dikaitkan dengan pendapat Suparno dan M. Yunus (2008:3) bahwa menulis adalah suatu kegiatan penyampaian pesan (komunikasi) dengan menggunakan bahasa tulisan sebagai alat medianya. Selain itu, Akhadiah (1997:41) berpendapat bahwa menulis merupakan suatu proses bernalar. Penalaran merupakan suatu proses berpikir yang sistematik untuk memperoleh kesimpulan berupa pengetahuan. Dengan demikian, menulis dapat diartikan sebagai bentuk menuangkan ide, gagasan, atau pokok pikiran ke dalam bahasa tulis yang berupa rangkaian kalimat yang utuh, lengkap, dan dapat dikomunikasikan kepada orang lain.

\section{Hakikat Menulis}

Menulis merupakan suatu keterampilan berbahasa yang dipergunakan untuk berkomunikasi secara tidak langsung. Hal ini dapat dikaitkan dengan pendapat Suparno dan M. Yunus (2008:3) bahwa menulis adalah suatu kegiatan penyampaian pesan (komunikasi) dengan menggunakan bahasa tulisan sebagai alat medianya. Selain itu, Akhadiah (1997:41) berpendapat bahwa menulis merupakan suatu proses bernalar. Penalaran merupakan suatu proses berpikir yang sistematik untuk memperoleh kesimpulan berupa pengetahuan. Dengan demikian, menulis dapat diartikan sebagai bentuk menuangkan ide, gagasan, atau pokok pikiran ke dalam bahasa tulis yang berupa rangkaian kalimat yang utuh, lengkap, dan dapat dikomunikasikan kepada orang lain.

Tujuan menulis menurut Hartig (dalam Tarigan 1986:25) adalah:

a) Assignment purpose (tujuan penugasan)

Penulis menulis sesuatu karena ditugaskan, bahkan atas kemauan sendiri (misalnya para siswa yang diberi tugas merangkumkan buku, sekretaris ditugaskan membuat laporan). 
b) Altruistic Purpose (tujuan altruistik)

Penulis bertujuan untuk menyenangkan para pembaca, menghindarkan kedukaan pembaca, ingin menolong para pembaca memahami, menghargai perasaan dan penalarannya, ingin membuat hidup para pembaca lebih mudah dan lebih menyenangkan dengan karyanya itu.

c) Persuasive Purpose (tujuan persuasif)

Tulisan yang bertujuan meyakinkan para pembaca akan kebenaran gagasan yang diutarakan.

d) Informational Purpose (tujuan informasi, tujuan penerangan)

Tulisan yang bertujuan memberi informasi atau keterangan atau penerangan kepada para pembaca.

e) Self-Expressive Purpose (tujuan pernyataan diri)

Berdasarkan tujuan menulis menurut Hartig (dalam Tarigan) dapat diperoleh kesimpulan bahwa menulis hendaknya dilakukan secara sistematis yakni mulai dari penugasan, tujuan altruistik, tujuan purpose, tujuan informasi dan tujuan penerangan, dan tujuan pernyataan diri. Sehingga apabila kelima unsur tersebut telah ada dalam rangkaian tujuan menulis akan tercipta sebuah hasil penulisan yang baik dan benar.

\section{Hakikat Puisi}

Secara etimologi, istilah puisi berasal dari bahasa Yunani, poeima "membuat" atau poeisis "pembuatan", dan dalam bahasa Inggris disebut poem atau poetry. Puisi diartikan "membuat dan "pembuatan karena lewat puisi pada dasarnya seseorang telah menciptakan suatu dunia tersendiri, yang mungkin berisi pesan atau gambaran suasana-suasana tertentu, baik fisik maupun batiniah (Aminuddin, 2002:134). Unsur fisik dan unsur batin lazim disebut bahasa dan isi atau tema dan struktur atau bentuk dan isi. Namun dalam sebuah puisi tidak semua peristiwa diceritakan. Hal yang dikemukakan dalam puisi hanyalah inti masalah, peristiwa, atau inti cerita.

Secara ringkas hal yang ditulis dalam puisi adalah esensi sesuatu karena puisi itu berupa pemadatan cerita, penyair memilih kata dengan cermat. Kata-kata yang dipilih harus bisa mewakili ekspresi perasaan penyair sehingga puisi merupakan ekspresi esensi, yaitu puisi menjadi suatu karya seni (mengandung unsur estetik) yang mengandalkan keindahan kata, gaya bunyi, gaya kata, gaya kalimat, wacana dan tipografinya. Kepuitisan dapat dicapai dengan bermacam-macam cara, misalnya dengan bentuk visual: tipografi, susunan bait; dengan bunyi: persajakan, asonansi, aliterasi, kiasan bunyi, lambang rasa, dan orkestrasi; dengan pemilihan kata (diksi), bahasa kiasan, sarana retorika, unsur-unsur ketatabahasaan, gaya bahasa dan sebagainya. Antara unsur pernyataan (ekspresi), sarana kepuitisan, yang satu dengan yang lainnya saling membantu, saling memperkuat dengan kesejajarannya ataupun pertentangannya untuk mendapatkan kepuitisan yang seefektif mungkin, seintensif mungkin (Pradopo, 2000:13). Sejalan dengan itu, Herman J. Waluyo (2002:1) memberikan pengertian puisi sebagai karya sastra dengan bahasa yang dipadatkan, dipersingkat, dan diberikan irama dengan bunyi yang padu dan pemilihan kata-kata kias (imajinatif).

Wellek dan Warren (1990:25) mengemukakan bahwa ada tiga aspek yang perlu diperhatikan untuk memahami hakikat puisi. Ketiga aspek tersebut adalah 1) sifat seni atau fungsi seni; 2) kepadatan; dan 3) ekspresi tidak langsung. Meskipun puisi sepanjang waktu selalu berubah yanng disebabkan oleh evolusi selera dan perubahan konsep estetik. Akan tetapi aspek penulisan puisi tetap diperhatikan dan ada hal yang tidak berubah, yakni puisi itu mengucapkan sesuatu hal dengan arti yang lain. Ketidaklangsungan itu menurut Riffaterre (Pradopo, 2000:12) disebabkan oleh tiga hal, yaitu 1) penggantian makna; 2) penyimpangan; dan 3) penciptaan makna. Penggantian makna terjadi pada ambiguitas, kontradiksi, dan 
nonsense, sedangkan penciptaan arti terjadi pada pengorganisasian ruang teks, seperti penyejajaran tempat (homologues), enjabemen dan tipografi. Puisi merupakan rekaman dan interprentasi pengalaman manusia yang penting, diubah dalam wujud yang paling berkesan.

\section{Unsur-Unsur Puisi}

Unsur puisi merupakan segala elemen yang dipergunakan penyair dalam membangun atau menciptakan puisinya. Wellek (dalam Aminuddin, 2002:149) membagi unsur pembangun puisi meliputi 1) lapis bunyi (sound stratum); 2) lapis arti (unit of meaning); 3) lapis dunia (realita dunia yang digambarkan penyair); 4) lapis dunia yang dipandang dari titik pandang tertentu; dan 5) lapis dunia yang bersifat metafisis. Sedangkan Sutedjo Kasnadi (2008:1) berpendapat bahwa puisi biasanya juga mengandung beberapa unsur ekstrinsik yaitu 1) aspek pendidikan; 2) aspek sosial budaya; 3) aspek sosial masyarakat; 4) aspek politik; 5) aspek ekonomi; dan 6) aspek adat.

Struktur batin puisi, yaitu : Tema. Tema merupakan gagasan pokok atau subject-matter yang dikemukakan oleh penyair. Pokok pikiran atau pokok persoalan itu begitu kuat mendesak dalam jiwa penyair, sehingga menjadi landasan utama pengucapannya. Contoh tema puisi sesuai dengan Alam antara lain tema keindahan laut, gunung atau sawah atau bencana alam yang dapat terjadi.Perasaan (Feeling). Dalam menciptakan puisi, suasana perasaan penyair ikut diekspresikan dan harus dapat dihayati oleh pembaca. Untuk mengungkapkan tema yang sama, penyair yang satu dengan perasaan yang berbeda dari penyair lainnya, sehingga hasil puisi yang diciptakan berbeda pula.Nada dan Suasana. Nada merupakan sikap penyair terhadap pembaca, sedangkan susasana adalah keadaan jiwa pembaca setelah membaca puisi itu atau akibat psikologis yang ditimbulkan puisi itu terhadap pembaca.

\section{Amanat (Pesan)}

Amanat yang hendak disampaikan oleh penyair dapat ditelaah setelah kita memahami tema, rasa, dan nada puisi. Unsur itu dapat ditelaah satu persatu, tetapi unsur-unsur itu merupakan kesatuan yang utuh. Puisi sebagai suatu kesatuan unsur-unsur fisik dan batin tersebut, maka penilaian atas puisi harus memperhatikan semua unsur yang terkandung didalamnya.

\section{Keterampilan Menulis Puisi}

Keterampilan atau kemampuan menulis puisi adalah kemampuan mengungkapkan gagasan, pendapat, dan persaan kepada pihak lain dengan mengungkapkan bahasa tulis yang bersifat literer (Depdiknas, 2003:8). Ketepatan pengungkapan gagasan tersebut harus didukung oleh kemampuan bersastra. Selain itu, Sayuti (2002:2) menyatakan bahwa menulis kreatif puisi pada hakikatnya adalah menafsirkan kehidupan. Penafsiran yang diungkapkan melalui karya kreatif puisi adalah tafsiran dengan melihat sisi lain dari kehidupan, merasakan kehidupan dengan kepekaan perasaan dan kemudian disampaikan melalui tulisan, salah satunya adalah puisi. Oleh sebab itu, puisi harus bersifat akpresiatif, imajinatif, dan ekspresif. Dalam penulisan puisi, menurut Jalil (1990:12), penyair akan mencurahkan segala aspirasinya dengan batasan teoritis kepenyairan yang relatif dan lebih mudah secara sadar dan secara kebetulan. Teoritisnya adalah lebih cenderung mencurahkan kehendak, perasaan dan gejolak batinnya dalam bentuk syair (puisi/sajak). Kemudian aspirasinya lebih tegas mengungkapkan koreksi terhadap hidupnya sendiri atau gejolak lingkungan. Relatifnya bahwa curahan syair setiap penyair selalu berbeda pengungkapannya walaupun sifatnya sama yaitu tumbuh berdasarkan rasio dan perasaan.

Keterampilan menulis bagi seorang siswa dapat diartikan sebagai sebuah proses berpikir dan membantu untuk lebih berpikir kritis mengenai kejadian-kejadian yang terjadi pada diri sendiri atau di sekelilingnya. Proses berpikir dalam pembelajaran ini menjembatani antara imajinasi dan penciptaan karya sastra yang akhirnya menghasilkan sebuah puisi yang indah. Melalui keterampilan menulis kreatif puisi, 
siswa diharapkan dapat menciptakan sebuah karya melalui proses berpikir dan pengalamannya. Berdasarkan hal tersebut, model Project BasedLearning (PBL) dapat menjadi salah satu alternatif pembelajaran pada mahasiswa. Pembelajaran model ini bertujuan untuk memunculkan atau merasakan kembali pengalaman dalam menulis karya puisi.

\section{Langkah-langkah Menulis Puisi}

Menurut Sutedjo Kasnadi (2008:34) menulis puisi biasanya berkaitan dengan beberapa hal yaitu 1) pencarian ide (ilham); 2) pemilihan tema; 3) Pemilihan aliran; 4) penentuan jenis puisi; 5) pemilihan diksi ( kata ) yang padat dan khas; 6) pemilihan permaianan bunyi; 7) pembuatan larik yang menarik; 8) pemilihan pengucapan; 9) pemanfaatan gaya bahasa; 10) pembaitan yang memiliki satu subject matter; 11) pemilihan tipografi; 12) pemuatan aspek psikologis (kejiwaan); 13) pemuatan aspek sosiologis (sosial kemasyarakatan); 14) penentuan tone dan feeling dalam puisi; 15) pemuatan pesan (meaning); dan 16) pemilihan judul yang menarik.

Menurut Jalil (1990:16) dalam proses penciptaan sebuah puisi terlebih dahulu yang harus kita pahami adalah mengenai hidup dan kehidupan sosial. Karena dari sebuah karya puisi yang baik di dalamnya tercermin bagian dari bentuk serta perikehidupan sosial dengan maksud menyampaikan segala aspirasi yang timbul. Baik yang ada dalam diri si penyair maupun gejolak yang ada dalam masyarakat, yang kedua pihak ini terekrut dalam suatu lingkungan sosial. Jalil (1990:18) menyimpulkan ada enam tahap dalam proses penciptaan puisi berikut ini.

a. Tahap Pengalaman. Pada tahap ini, seorang penyair atau calon penyair untuk mengetahui secara aktual setiap peristiwa yang berkaitan dengan apa yang akan dituangkan dalam sebuah karya puisi, yang lebih utama mengalami sendiri.

b. Tahap Penafsiran. Tahap penafsiran adalah suatu kebulatan pikiran yang sementara dan pandangan sementara pula terhadap suatu peristiwa atau terhadap suatu pengalaman yang mampu diungkapkan secara tertulis.

c. Tahap Penilaian. Tahap penilaian adalah tahap penyair melakukan penilaian yang akan menentukan benar tidaknya suatu peristiwa. Dalam tahap ini akan dijadikan penyair bisa beradaptasi dengan lingkungan dan membuat dirinya dapat berdisiplin dalam segala tindakan.

d. Tahap Penghayatan. Yang dilakukan penyair dalam proses penghayatan adalah menegakkan keutuhan suatu peristiwa dengan seutuh-utuhnya. Atau lebih dalam lagi kita bertindak sebagai seorang filsuf.

e. Tahap Memutuskan. Tahap ini sangat penting karena seorang penyair dalam memutuskan gagasan atau idenya dari suatu peristiwa terhadap karya puisi, terletak pada pertimbangan atas peristiwa yang dihadapinya. Persoalannya adalah mengenai sikap si penyair serta reaksinya terhadap lingkungan sosial yanga aktual.

f. Tahap Pencurahan. Tahap pencurahan, yaitu bersatunya segala aspek dan terekrutnya segala proses yang telah bulat, sehingga segala inspirasi itu jelas dapat dituangkan ke dalam bentuk karya puisi. Proses pencurahan merupakan proses yang sangat menentukan hasil cipta karya puisi, oleh karena itu sangat diperlukan konsentrasi dalam pengungkapan dan pencurahannya (Wiyanto, 2005:57).

Menulis puisi sebenarnya mengungkapkan gagasan dalam bentuk puisi. Gagasan itu dilandasi oleh tema tertentu. Oleh karena itu, sebelum menulis sebuah puisi lebih dahulu kita harus menentukan temanya, yaitu pokok persoalan yang akan dikemukakan dalam puisi. Tema itu kemudian kita kembangkan dengan menentukan hal-hal apa yang akan dikemukakan dalam puisi. Dalam menulis puisi, kita harus memilih katakata yang tepat, bukan hanya tepat maknanya, melainkan juga harus tepat bunyi-bunyinya dan menyusun kata-kata itu demikian rupa sehingga menimbulkan kesan estetis. Selain itu, kita juga harus mendayagunakan 
majas agar puisi yang kita buat semakin baik. Tahap-tahap dalam menulis puisi menurut Parera adalah sebagai berikut.

a. Tahap prakarsa. Tahap prakarsa merupakan tahap pencarian idea untuk dituangkan dalam bentuk tulisan yang berupa puisi. Ide itu dapat berupa pengalaman seseorang untuk melakukan tugas atau memecahkan masalah tertentu.

b. Tahap pelanjutan. Tahap pelanjutan merupakan tahap tindak lanjut dari tahap pencarian ide setelah seseorang mendapatkan ide dari berbagai sumber dan cara kemudian dilanjutkan dengan mengembangkan ide tersebut menjadi puisi.

c. Tahap pengakhiran. Setelah dilakukan penilaian maka dilakukan revisi tahap pengakhiran ini setelah mencapai peningkatan dalam proses penulisan puisi (dalam Widowati, 2007:23-24).

Di samping itu latihan penulisan puisi tidak hanya untuk mempertajam pengamatan dan peningkatan kemampuan bahasa, akan tetapi siswa diharapkan tanggap terhadap realitas sosial yang ada,menjadi manusia yang peduli terhadap lingkungan.

\section{Penilaian dalam Pembelajaran Menulis Puisi}

Penilaian merupakan suatu kegiatan dalam pembelajaran yang memiliki peranan penting serta memberikan manfaat terhadap pencapaian hasil belajar siswa. Salah satu manfaat dari penilaian yaitu digunakan sebagai umpan balik kepada siswa maupun guru. Penilaian berfungsi untuk mengukur sejauh mana kemampuan siswa, sedangkan bagi guru penilaian berfungsi untuk memperbaiki kegiatan dan metode yang digunakan dalam proses pembelajaran. Berdasarkan Peraturan Menteri Pendidikan dan Kebudayaan Republik Indonesia Nomor 65 Tahun 2013 tentang Standard Proses Pendidikan Dasar dan Menengah, penilaian proses pembelajaran dilakukan menggunakan pendekatan penilaian otentik (authenticassesment) yang menilai kesiapan siswa, proses, dan hasil belajar secara utuh.Kegiatan menulis puisi merupakan bagian dari penulisan kreatif sastra. Sebagai kegiatan kreatif, puisi dapat dikembangkan secara bertahap, kontinyu, terarah, dan terintegrasi. Roekhan (1991:5-6) menyatakan bahwa hal yang harus diperhatikan agar siswa menghasilkan karya sastra (puisi) yang kreatif adalah 1) kemampuan berpikir kritis; 2) kepekaan emosi; 3) bakat (bakat ini dapat dilatih); dan 4) daya imajinasi yang mampu mengasosiasikan apa yang ditangkap indera. Rubrik penilaian puisi menurut Burhan Nurgiantoro (2012: 487), (1) kebaharuan tema dan makna, (2) kekuatan imajinasi, (3) ketepatan diksi, (4) pendayaan pemajasan dan citraan.

\section{Project Based Learning}

Project Based Learning (PBL) merupakan metode belajar yang menggunakan masalah sebagai langkah awal dalam pengumpulan dan mengintegrasikan pengetahuan baru berdasarkan pengalamannya dalam beraktivitas secara nyata. Menurut Thomas, dkk (dalam Wena, 2011:144), PBL merupakan model pembelajaran yang memberikan kesempatan kepada guru untuk mengelola pembelajaran di kelas dengan melibatkan kerja projek. Definisi secara lebih komperehensif tentang Project Based Learning menurut The George Lucas. PBL merupakan investigasi mendalam tentang sebuah topik dunia nyata, hal ini akan berharga bagi usaha siswa. Mengingat bahwa masing-masing siswa memiliki gaya belajar yang berbeda, maka PBL memberikan kesempatan kepada para siswa untuk menggali materi dengan menggunakan berbagai cara yang bermakna serta melakukan eksperimen secara kolaboratif. Ditunjang dengan Peraturan Menteri Pendidikan dan Kebudayaan Republik Indonesia Nomor 65 Tahun 2013 tentang Standard Proses Pendidikan Dasar dan Menengah, untuk mendorong kemampuan peserta didik menghasilkan karya kontekstual, baik individual maupun kelompok maka sangat disarankan menggunakan pendekatan pembelajaran yang menghasilkan karya berbasis pemecahan masalah (project based learning). 
Penerapan PBL pada materi menulis puisi bebas diawali dengan menetapkan tujuan yang ingin dicapai dalam menghasilkan produk berupa puisi. Selanjutnya, guru sebagai mediator dan fasilitator menyajikan alat belajar berupa media gambar atau memanfaatkan lingkungan sekolah sebagai sumber belajar, peraturan kerja, pembagian tugas. Pembelajaran di kelas bertumpu pada kegiatan aktif siswa maka keterlibatan siswa secara berkelompok dan berdiskusi terhadap proses pengamatan dan pengumpulan data. Tahap menulis puisi bebas, diarahkan dengan memunculkan pertanyaan penuntun dan membimbing siswa dalam sebuah projek kolaboratif yang mengintegrasikan berbagai data untuk mengungkap makna pembelajaran sehingga siswa dapat mengidentifikasi materi dan prinsip penulisan puisi yang sedang dikajinya.

Berdasarkan latar belakang tersebut, penelitian ini memiliki rumusan masalah sebagai berikut (1) Bagaimanalangkah-langkah pembelajaran menulis puisi berbasis model Project Based Learningpada mahasiswa prodi managemen tahun ajaran 2017/2018? (2) Bagaimana hasil menulis puisi pada mahasiswa prodi managemen berbasis model Project Based Learning tahun ajaran 2017/2018? Adapun tujuan penelitian ini adalah (1) Untuk mengetahui langkah-langkah pembelajaran menulis puisi berbasis model Project Based Learning menulis puisi pada mahasiswa prodi managemen tahun ajaran 2017/2018. (2) Untuk megetahui hasil menulis puisi pada mahasiswa prodi manajemen berbasis model Project Based Learning tahun ajaran 2017/2018.

\section{METODE PENELITIAN}

\section{Desain Penelitian}

Moleong (1984:26) mengungkapkan bahwa penelitian kualitatif adalah penelitian yang bermaksud untuk memahami fenomena tentang apa yang dialami oleh subjek penelitian misalnya perilaku, persepsi, motivasi, tindakan dan lain-lain secara holistik dan dengan cara deskripsi dalam bentuk kata-kata dan bahasa, pada suatu konteks khusus alamiah dan dengan memanfaatkan berbagai metde alamiah.

Desain penelitian yang digunakan dalam penelitian ini adalah deskripsi kualitatif dan kuantitatif. Penelitian kualitatif digunakan untuk memperoleh gambaran empiris mengenai kemampuan menulis puisi berbasis model Project Based Learning.

\section{Sumber Data}

Sumber data pada penelitianan ini berupa hasil analisis puisi. karya mahasiswa prodi manajemen.

\section{Prosedur Penelitian}

Tahap prosedur penelitian ini adalah a) mengumpulkan data berupa puisi mahasiswa, b) penyeleksian data yang telah terkumpul, kemudian diseleksi serta dipilah-pilah untuk selanjutnya akan dianalisis, c) menganalisis data yang telah diseleksi, d) data yang telah diseleksi kemudian akan di analisis, e) membuat laporan penelitian. Pembuatan laporan penelitian adalah tahap terakhir dari serangkaian proses penelitian yang telah dilakukan. Dalam tahap ini penyampaian data yang telah dianalisis, dirumuskan, selanjutnya menarik kesimpulan

\section{Analisis Data}

Penelitian ini menggunakan teknik analisis data berupa model analisis mengalir, meliputi tiga komponen yaitu 1) reduksi data; 2) penyajian data; 3) penarikan simpulan. Analisis model mengalir mempunyai tiga komponen yang saling terjalin dengan baik, yaitu sebelum, selama dan sesudah pelaksanaan pengumpulan data. 


\section{PEMBAHASAN}

1. Langkah-langkah Kegiatan Pembelajaran menggunakan model pembelajaran Problem Based Learning (PBL) adalah sebagai berikut.

a. Kegiatan Awal

1. Dosen menanyakan kesiapan mahasiswa

2. Dosen memberikan apersepsi

3. Dosen menyampaikan tujuan pembelajaran

b. Kegiatan Inti

1. Mahasiswa dan dosen bertanya jawab mengenai puisi, unsur-unsur yang harus diperhatikan dalam puisi.

2. Mahasiswa diperlihatkan contoh puisi

3. Mahasiswa dibagi menjadi beberapa kelompok heterogen dengan anggota 4-5 orang.

4. Dosen membagikan materi yang harus dikerjakan oleh mahasiswa serta petunjuk pelaksanaannya

5. Mahasiswa mendiskusikan tentang masalah apa yang akan diangkat di dalam tulisan serta harus membuat secara lengkap unsur-unsur yang harus ada di dalam puisi

6. Mahasiswa mengkontruksikan sendiri pengetahuan yang didapat ke dalam bentuk puisi.

c. Kegiatan Akhir

1. Mahasiswa dan guru mengadakan refleksi tentang proses dan hasilbelajar.

2. Dosen mengakhiri perkuliahan.

2. Analisis hasil menulis puisi pada mahasiswa prodi managemen berbasis model Project Based Learning tahun ajaran 2017/2018 secara keseluruhan diperoleh hasil sebagai berikut.

\begin{tabular}{|l|l|}
\hline \multicolumn{1}{|c|}{ Unsur } & Analisis Puisi Berbasis Model Project Based Learning \\
\hline Kebaharuan tema dan makna & $\begin{array}{l}\text { Mampu menciptakan gagasan diungkapkan secara jelas, padat, } \\
\text { dan tertata dengan baik dengan urutan yang logis. }\end{array}$ \\
\hline Kekuatan imajinasi & $\begin{array}{l}\text { Konstruksi imajinasi kompleks dan efektif terdapat pada setiap } \\
\text { puisi. }\end{array}$ \\
\hline Ketepatan diksi & $\begin{array}{l}\text { Pemanfaatan potensi kata canggih, pilihan kata dan ungkapan } \\
\text { tepat, menguasai pembentukan kata. }\end{array}$ \\
\hline $\begin{array}{l}\text { Pendayaan pemajasan dan } \\
\text { citraan }\end{array}$ & $\begin{array}{l}\text { Tingkat penciptaan majas dan citraan kompleks sarat dengan } \\
\text { makna dari puisi tersebut. }\end{array}$ \\
\hline
\end{tabular}

Berdasarkan hasil analisis tersebut secara keseluruhan penerapan model Problem Based Learning pada kegiatan menulis puisi mahasiswa Prodi Managemen telah memenuhi struktur penulisan puisi dengan baik. Secara keseluruhan mahasiswa telah mampu menulis puisi dengan menerapkan empat unsur penting dalam struktur penulisan puisi dengan mengaplikasikan model Problem Based Learning. Empat unsur 
tersebut menjadikan mahasiswa merasa menulis puisi tidak mudah namun juga tidak sulit. Setiap unsur telah teraplikasikan dengan baik, sehingga mahasiswa merasa senang dan suka menulis puisi.

\section{PENUTUP}

Langkah-langkah pembelajaran menulis puisi berbasis model Project Based Learning pada mahasiswa prodi managemen meliputi kegiatan awal yaitu dosen menanyakan kesiapan siswa, memberikan apersepsi dan menyampaikan tujuan pembelajaran, kegiatan inti mahasiswa dan dosen bertanya jawab mengenai puisi, unsur-unsur yang harus diperhatikan dalam puisi, mahasiswa diperlihatkan contoh puisi, mahasiswa dibagi menjadi beberapa kelompok heterogen dengan anggota 4-5 orang, dosen membagikan materi yang harus dikerjakan oleh mahasiswa serta petunjuk pelaksanaannya, mahasiswa mendiskusikan tentang masalah apa yang akan diangkat di dalam tulisan serta harus membuat secara lengkap unsur-unsur yang harus ada di dalam puisi, mahasiswa mengkontruksikan sendiri pengetahuan yang didapat ke dalam bentuk puisi, kegiatan akhir mahasiswa dan dosen mengadakan refleksi tentang proses dan hasilbelajar dosen menutup perkuliahan.

Hasil menulis puisi pada mahasiswa prodi manajemen berbasis model Project Based Learningmeliputi (1) kebaharuan tema dan makna mahasiswa mampu menciptakan gagasan diungkapkan secara jelas, padat, dan tertata dengan baik dengan urutan yang logis (2) kekuatan imajinasi mahasiswa mampu mengkonstruksi imajinasi kompleks dan efektif terdapat pada setiap puisi (3) Ketepatan diksi, pemanfaatan potensi kata canggih, pilihan kata dan ungkapan tepat, menguasai pembentukan kata (4) pendayaan pemajasan dan citraan, (5) tingkat penciptaan majas dan citraan kompleks sarat dengan makna dari puisi tersebut.

\section{DAFTAR PUSTAKA}

Akhadiah, Hartig, Akhadiah, Sabarti et al, 1997,Pembinaan Kemampuan Menulis Bahasa Indonesia, Jakarta: Erlangga.

Chaer, Abdul. 2006. Tata Bahasa Praktis Bahasa Indonesia (Edisi Revisi). Jakarta: PT.Rineka Cipta.

Jalil, Danie Abdul. 1990. Teori dan Periodisasi Puisi Indonesia. Bandung: Angkasa.

Nurgiyantoro, Burhan. 2012. Penilaian dalam Pengajaran Bahasa dan Sastra, Yogyakarta: BPEF

Pradopo, Rahmat Djoko, 2000, Pengkajian Puisi, Yogjakarta: Gajah Mada University Press.

Roekhan, 1991, Menulis Kreatif, Dasar-dasar dan Petunjuk Penerapannya, Malang, YA3 Malang.

Sayuti, Suminto. A, 2002, Berkenalan dengan Puisi, Surakarta, Widya Duta.

Suparno dan M. Yunus, Suparno dan Muhammad Yunus, 2008. Keterampilan Dasar Menulis. Jakarta: Universitas Terbuka.

Sutedjo Kasnadi, 2008,Menulis Kreatif Kiat Cepat Menulis Puisi dan Cerpen, Yogjakarta: Nadi Pustaka. 
Waluyo, Herman J, 1987,Teori dan Apresiasi Puisi, Jakarta: Erlangga.

Wellek, Rene dan Austin Weren, 1990,Teori Kesusastraan, Terjemahan Meilani Budianto, Jakarta: Gramedia.

Wiyanto, Asul. 2005. Kesusastraan Sekolah. Jakarta: Grasindo. 